\title{
Antioxidant and cytotoxic activity of Tecoma stans against lung cancer cell line (A549)
}

\author{
Jayachandran Philip Robinson*, Kumaresan Suriya, Ramasamy Subbaiya, Ponnusamy \\ Ponmurugan
}

Department of Biotechnology, K.S.Rangasamy College of Technology, Trichengode, Tamil Nadu, India

\begin{abstract}
Human have been constantly using plants and plant products to overcome many diseases. The antioxidant property of the plant sources is studied to obtain an efficacious drug against cancer. The objectives of the present study is to evaluate the antioxidant and cytotoxic activity of the Tecoma stans extracts against lung cancer cell line in comparison with vincristine drug. The antioxidant activity was studied using the standard DPPH assay and the cytotoxic activity using MTT assay. DPPH assay results show that methanolic extract of $T$. stans in higher concentration show better antioxidant potential than the standard $\mathrm{L}$-ascorbic acid. They exhibited strong antioxidant potential at $20 \mu \mathrm{g} / \mathrm{mL}$ concentration. The absorbance at $517 \mathrm{~nm}$ showed that in the range of 0.201-0.0203 compared to that of absorbance of ascorbic acid at 0.023. Cytotoxic activity was studied using MTT assay which showed that the increase in concentration of extract increases the cell death. At $100 \mu \mathrm{g} / \mathrm{mL}$ concentration there is an increased cytotoxic activity, i.e., $99 \%$ of cell inhibition. The results of antioxidant and anticancerous activity may be positively correlated.
\end{abstract}

UNITERMS: Tecoma stans/extract/cytotoxicity. Tecoma stans/extract/antioxidant activity. Free radical scavenging. Plant extracts. Lung cancer cell line/study/drugs.

\section{INTRODUCTION}

Cancer is one of the disease that occurs in both developed and developing countries and is the leading cause of death. An extensively used treatment for cancer is chemotherapy and one of the major drawbacks is the toxicity that is caused to the normal cells due to the inability of the chemical drugs to differentiate between normal and cancerous cells (Balamurugan et al., 2014). Traditional medicines have been tested and researched upon to obtain an effective drug against cancer. Plant derived compounds are widely studied for their holistic value. These plant derived compounds have clinical significance which can be further developed into effective drugs against cancer. Bio active compounds have received the attention of researchers to overcome the burden of chemotherapy related problems. Oncovin is the brand name for vincristine, which is used as a chemotherapy drug for many types of cancer. Vincristine is also used to

\footnotetext{
*Correspondence: J. P. Robinson. Department of Biotechnology. K.S.Rangasamy College of Technology. Trichengode, Namakkal District. Tamil Nadu, India. E-mail: philiprobin81@gmail.com
}

treat neurodegenerative disease (Chun-Fai et al., 2013). The mode of action of vincristine is that it acts on the tubulin protein, thereby inhibiting the metaphase stage, thus leading the cell to apoptosis (Jordan, 2002).

Tecoma Stans is an ornamental tree that has its origin from the Americas belongs to the family Bignoniaceae. Presently the plant is widely cultivated throughout India for its flowers which bloom throughout the year. Presence of alkaloids tecomine and tecostamine which are potential hypoglycemic agents present in the leaves of T. stans. In addition to that presence of also anthranilic acid in the roots of plant which is an antidiabetic agent (Khare, 2007). There are a number of compounds from the fruits and flowers of the Tecoma, which had antioxidant activity and anti proliferative effect against cancer cell lines (Marzouk et al., 2006). Antioxidants play a major role in deciding the pharmaceutical effect of plants and to make them potent drugs against the chronic diseases. These antioxidants are taken in our dietary from the plant compounds, which is a rapid and simple method. The DPPH assay is the simple method to evaluate the presence of antioxidants in any source based on the principle of radical scavenging activity. In this assay the (2, 2-diphenyl-1-picryl-hydrazyl- 
hydrate) i.e., DPPH is reduced to DPPHH, the odd element is formed is absorbed at $517 \mathrm{~nm}$ (Tailor, Goyal, 2014). The cytotoxic activity of the plant extract is studied using the 3-(4,5-dimethylthiazol-2-yl)-2,5- diphenyltetrazolium bromide (MTT) which forms formazan (insoluble) crystals, by interacting with the mitochondria of the cells and the insoluble formazan that is formed is solubilized using isopropanol solvent which is studied spectrophotometrically at $540 \mathrm{~nm}$. MTT is reduced only by metabolically active cells, thus in, turn it helps to study the viability of the cell.

\section{MATERIAL AND METHOD}

\section{Collection of plant material}

The fresh plant of Tecoma stans was collected from Paramathi velur, Namakkal district of Tamil Nadu, India. The collected plants were further surface sterilized using tween 80 and it was shade dried for future investigation.

\section{Preparation of plant extract}

$10 \mathrm{~g}$ of both fresh and dried leaves, flowers were chopped into fine pieces and macerated in $100 \mathrm{~mL}$ of methanol. The plant material was extracted at room temperature for 3 days in a shaker. The extract was filtered and the filtrate was concentrated in a rotary evaporator under reduced pressure to dryness. The extract obtained was stored at $4{ }^{\circ} \mathrm{C}$ until use.

\section{Antioxidant assay}

\section{DPPH assay}

The percentage of antioxidant assay was determined using the free radical scavenging activity (2, 2-diphenyl1-picryl-hydrazyl-hydrate). About $1 \mathrm{mg}$ of fresh and the dried plant extracts was dissolved in $1 \mathrm{ml}$ of methanol. The standard procedure for DPPH assay was performed based on Ochuko et al. (2012). About $10 \mathrm{~mL}$ of $0.1 \mathrm{mM}$ of DPPH was prepared in methanol and stored in cool dark condition until use. Accurately, $1 \mathrm{~mL}$ of DPPH was added to different concentration $(20,40,60,80,100 \mu \mathrm{g} /$ $\mathrm{mL}$ ) of T.stans extract. The mixture of DPPH and extract was shaken and incubated at room temperature in the dark for 30 minutes, then the absorbance was measured at 517 $\mathrm{nm}$ in the UV spectrophotometer (Tailor, Goyal, 2014). Ascorbic acid was used as a reference and DPPH without the extract served as negative control. The $\mathrm{IC}_{50}$ value of the sample was calculated based on the absorbance. The percentage of inhibition was calculated using the formula,
DPPH scavenging effect (\%) or

Percent inhibition $=($ Absorbance of sample-absorbance of blank)/Absorbance of Control X 100

\section{Lung Cancer (A549) cell line}

Lung cancer cell line (A549) cell line was procured from NCCS, Pune and maintained in Dulbecco's minimal essential medium (DMEM) with 10\% FBS, and antibiotic mixture (Penicillin, streptomycin and ampicillin 100 units/ $\mathrm{mL}$ ) under defined conditions of temperature at $37^{\circ} \mathrm{C}, 95 \%$ humidity and $5 \% \mathrm{CO}_{2}$.

\section{Cell viability assay}

The cytotoxic activity of the fresh and dried extracts of leaves and flowers of Tecoma stans was determined using the 3-(4,5-dimethylthiazol-2-yl)-2,5diphenyltetrazolium bromide (Terry et al., 1992). Tecoma stans extract concentrations were prepared in the range of $100-20 \mu \mathrm{g} / \mathrm{mL}$ from the stock solution by serial dilution using Dimethyl sulphoxide (DMSO). Vin-Cristine wide range anti-cancer drug was used as the standard $(0.1 \mathrm{~g} /$ $\mathrm{mL}$ ). Lung cancer cell line (A549) was trypsinised and the cells were counted using haemocytometer following standard procedure. $100 \mu 1$ of the lung cancer cell line at $1 \times 10^{4}$ cells $/ \mathrm{mL}$ was added to poly L-lysine coated 96 well plate and incubated at $37^{\circ} \mathrm{C}$ in a humidified $5 \% \mathrm{CO}_{2}$ incubator. After 24 hours of incubation, the old medium was replaced with fresh medium and $50 \mu \mathrm{L}$ of the extract was added and incubated for 48 hours at $37{ }^{\circ} \mathrm{C}$ in a humidified $5 \% \mathrm{CO}_{2}$ incubator. $30 \mu 1$ of $0.5 \% \mathrm{w} / \mathrm{v}$ MTT was added and incubated at room temperature for 4 hours. After incubation, $50 \mu \mathrm{L}$ of acid-isopropanol was added to dissolve the formazan formed and incubated at room temperature for 30 minutes. Then absorbance was taken at $554 \mathrm{~nm}$ using Bio-Rad micro-titer plate reader. The assay was performed in triplicates.

\section{RESULTS AND DISCUSSION}

Antioxidant property plays an important role in reducing chronic diseases like cancer and cardiovascular (CAD) diseases. Crude plant extracts are screened on cell culture, to determine their efficiency as a potential alternate drug and also to check their efficiency in clinical application as suggested by Balamurugan et al. (2014). Plants are primary resources for antioxidants like carotenes, phenolic acids, etc., the phytochemical analysis Tecoma stans revealed that the plant has alkaloids, steroids, glycosides and carbohydrates as suggested by 
(Prajapati, Patel, 2010). A number of flowers and fruits having anti oxidant activity have been identified in the flowers and fruits of Tecoma their effective anti-cancer activity was studied against cancer cell line (Marzouk et al., 2006).

DPPH assay is performed to study the radical scavenging activity, the scavenging activities in the present investigation were similar to that as reported by Erukainure et al. (2012), Where the scavenging activity follows a dose dependen pattern i.e., increase in activity to increase in concentration. The alcoholic and aqueous extract of T.stans on phytochemical analysis has revealed the presence of polyphenolic, $\beta$ - sitosterol and flavonoids. In earlier reports by Hamburger and Hostettmann (1991), Beltrame et al. (2002) and Suffredimi et al. (2004), these compounds have exhibited anti-bacterial, antiviral, immunological and cytotoxic property on different cancer cell lines.

The current study was carried out to report the antioxidant activity of the fresh and dried leaves and flowers of Tecoma stans using the DPPH assay. 1,1-diphenyl-2-picrylhydrazyl reacts with the antioxidants present in the plant extract and accepts the hydrogen atom, thus addition of hydrogen atom converts it to 1, 1-diphenyl-2-picrylhydrazine (Ochuko et al., 2012). The chemical 1, 1-diphenyl, 1-2- picrylhydrazyl changes from purple color to yellow color. In case of $T$ stans the antioxidant is higher from $20-100 \mu \mathrm{g} / \mathrm{mL}$ when compare to the standard of L-ascorbic acid at absorbance $517 \mathrm{~nm}$ in UV visible spectrophotometer. Table I shows the radical scavenging activity of T.stans against stable DPPH.

The scavenging activity values were compared with that of ascorbic acid (concentrations of 20,40,60,80 and $100 \mu \mathrm{g} / \mathrm{mL}$ ) the values were dose dependent and their percentage of inhibition show that at $20 \mu \mathrm{g} / \mathrm{mL}$ concentration the percentage inhibition was $99.98 \%$, which increase as $99 \%(40 \mu \mathrm{g} / \mathrm{mL}), 99.33 \%(60 \mu \mathrm{g} / \mathrm{mL})$, $99.67 \%(80 \mu \mathrm{g} / \mathrm{mL})$ and $99.79 \%(100 \mu \mathrm{g} / \mathrm{mL})$ for dried leaves and flowers while for fresh flowers and leaves its $99.98 \%(20,40 \mu \mathrm{g} / \mathrm{mL})$ and $99.99 \%(60,80,100 \mu \mathrm{g} / \mathrm{mL})$ respectively. These results were compared to standard ascorbic acid favorably.

From Figure 2 it is observed that cancer cells have undergone certain morphological changes, like cellular shrinkage and blebbing, which are characteristic features of apoptosis. These morphological changes are less observed in standard (vincristine) treated cells and these changes seem increasing with increase in concentration of

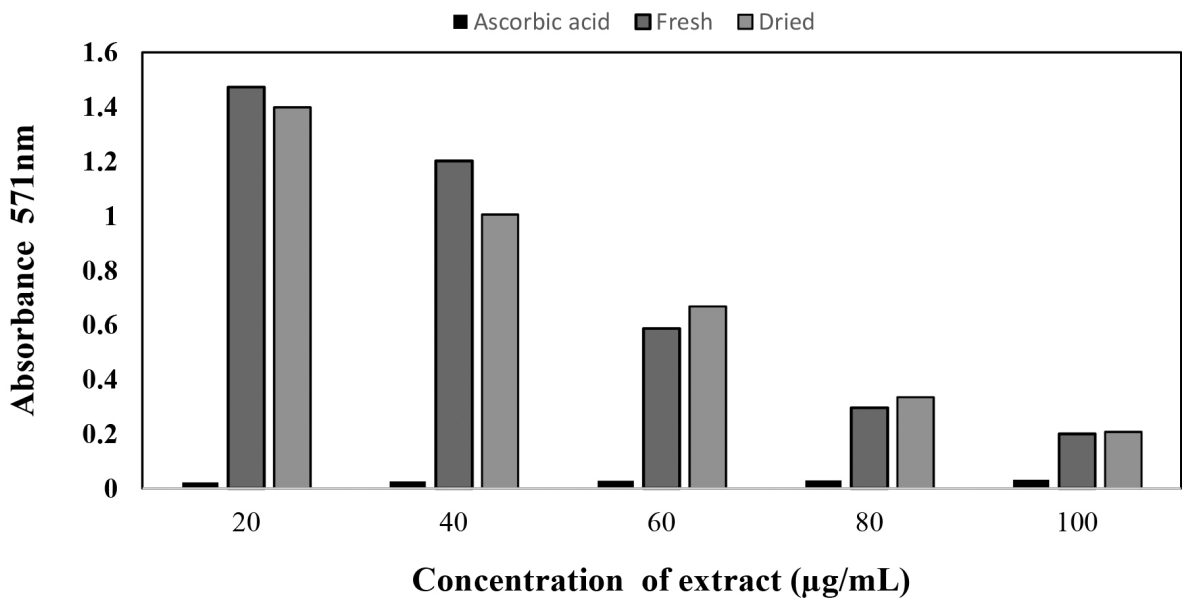

FIGURE 1 - Antioxidant activity of fresh and dried leaves and flowers of Tecoma stans in comparison with ascorbic acid at $517 \mathrm{~nm}$.

TABLE I - Absorbance and percentage of inhibition of Fresh and Dried extract of Tecoma stans

\begin{tabular}{lccccc}
\hline Control & $\begin{array}{c}\text { Ascorbic acid } \\
\mathbf{( 5 1 7 n m})\end{array}$ & $\begin{array}{c}\text { Fresh } \\
\mathbf{( 5 1 7} \mathbf{~ n m})\end{array}$ & $\begin{array}{c}\text { Percentage of } \\
\text { inhibition }\end{array}$ & $\begin{array}{c}\text { Dried } \\
\mathbf{5 1 7} \mathbf{~ n m})\end{array}$ & $\begin{array}{c}\text { Percentage of } \\
\text { inhibition }\end{array}$ \\
\hline $2.203 \pm 0.01$ & $0.023 \pm 0.01$ & $1.472 \pm 0.02$ & $98.60 \%$ & $1.398 \pm 0.02$ & $99.98 \%$ \\
$2.205 \pm 0.01$ & $0.025 \pm 0.02$ & $1.202 \pm 0.01$ & $99.00 \%$ & $1.005 \pm 0.01$ & $99.98 \%$ \\
$2.206 \pm 0.01$ & $0.028 \pm 0.01$ & $0.587 \pm 0.02$ & $99.33 \%$ & $0.668 \pm 0.01$ & $99.99 \%$ \\
$2.208 \pm 0.01$ & $0.03 \pm 0.02$ & $0.297 \pm 0.02$ & $99.67 \%$ & $0.335 \pm 0.02$ & $99.99 \%$ \\
$2.21 \pm 0.01$ & $0.032 \pm 0.01$ & $0.201 \pm 0.01$ & $99.79 \%$ & $0.208 \pm 0.02$ & $99.99 \%$ \\
\hline
\end{tabular}


the extract. At $100 \mu \mathrm{g} / \mathrm{mL}$ the morphological changes are higher, followed by $80 \mu \mathrm{g} / \mathrm{ml}$ concentration.

The antioxidant assay results further, directed the study towards cytotoxic assay. The phytochemical and antioxidant assay which showed the expression of carotenes and phytophenols, hence lung cancer cell line was chosen for cytotoxic activity. The results of MTT assay in Figure 3 show that the methanolic extract of Tecoma stans has high cytotoxic activity against the cancer cell line from $20 \mu \mathrm{g} / \mathrm{mL}$ concentration i.e., $99.3 \%$. Earlier reports confirm the better cytotoxic activity of the plant (Pusapathi et al., 2015).

Presence of phenolic compounds and its congers have shown to induce a cascade based apoptosis in cancer cells, thus inducing cytotoxicity (Owen et al., 2000). The cell viability of the lung cancer cell line decreased with increase in concentration of the plant extract and it was found to be the highest in $100 \mu \mathrm{g} / \mathrm{mL}$ concentration. The decrease in cell viability with increased concentration of the plant extract of Tecoma stans suggests the ability of the extract as an effective anti-cancer medicine. Antioxidant and free radical scavenging activity of the extract may be the reason behind its anti-cancer property.

\section{CONCLUSION}

The present investigation revealed that $T$. stans can act as a potential alternative remedy for lung cancer. The extract of T. stans can be used as an effective ingredient in drug recipe cancer. Further investigation is undertaken to identify the active compound behind the cytotoxic activity of the plant. The study in the future is to be extended to other cancer cell lines and there is a need to carry out in vivo studies to further authenticate the anti-oxidant potentials of this species.

\section{ACKNOWLEDGEMENT}

The authors are thankful to the Department of Science and Technology, New Delhi for the financial
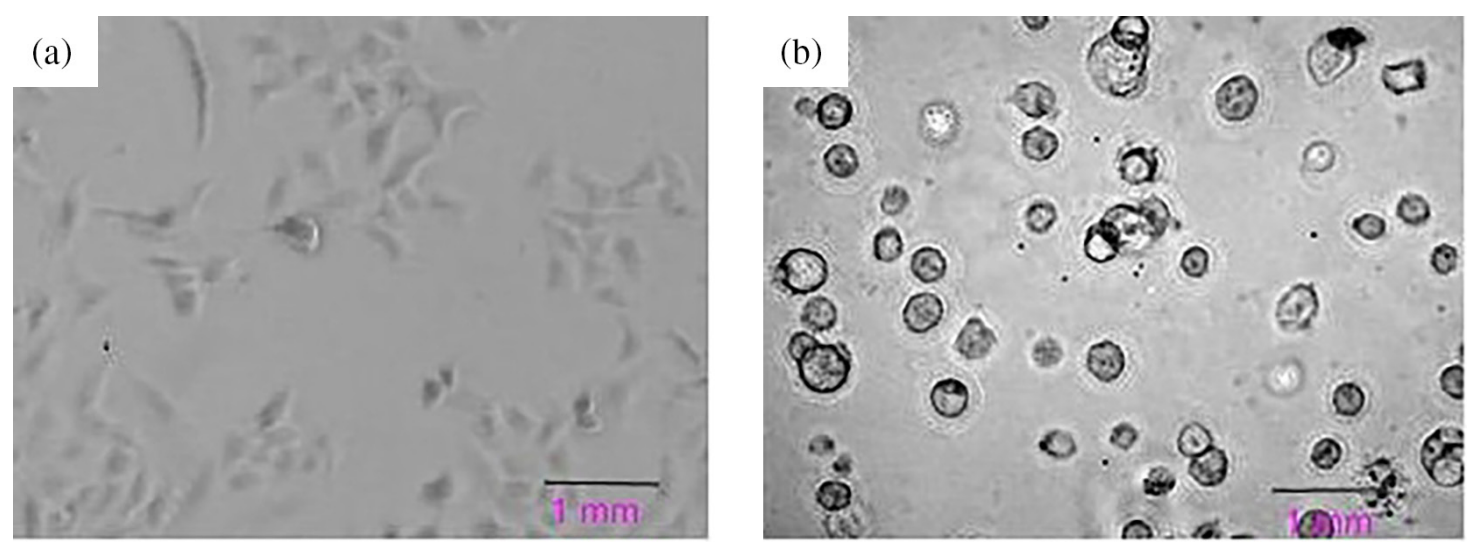

FIGURE 2 - Morphological changes of lung cancer cell lines after plant extract treatment a) Untreated lung cancer cells; b) T. stans treated lung cancer cells (after 24 hours).

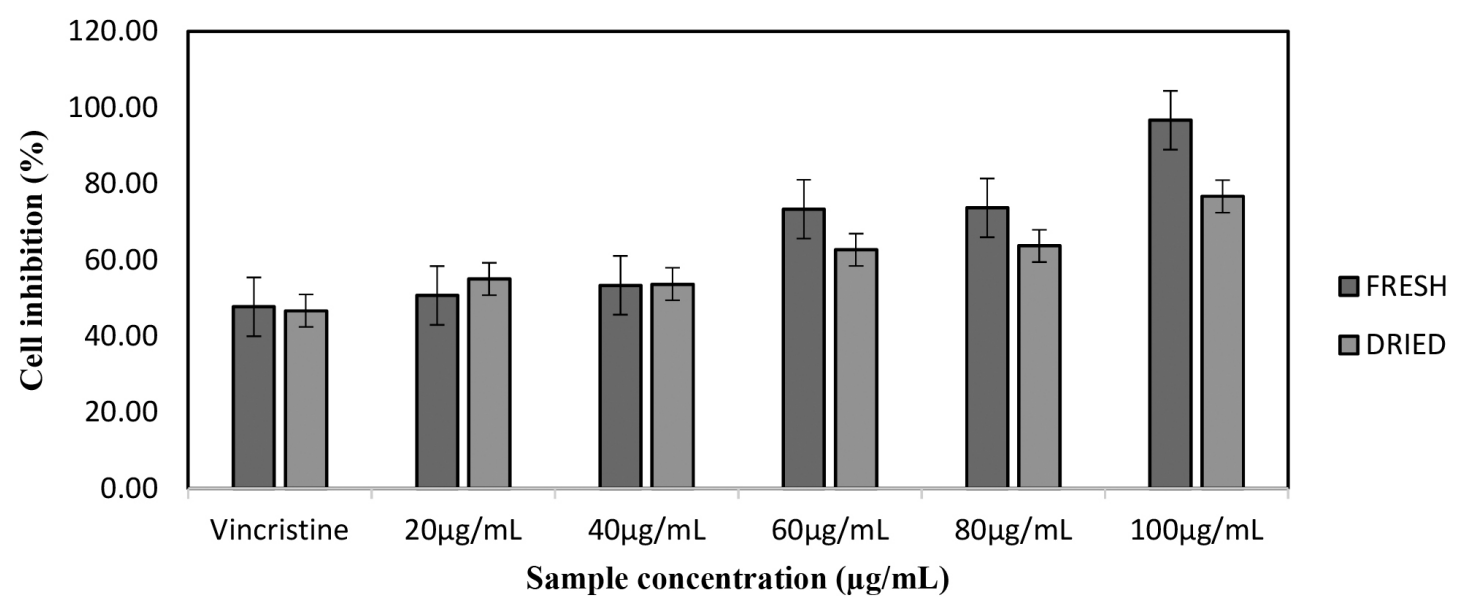

FIGURE 3 - Cytotoxic activity of Tecoma stans at different concentrations against Lung Cancer cell (A549). 
support through DST- FIST grant for the improvement of infrastructure facilities to the laboratories.

\section{REFERENCES}

Balamurugan V, Balakrishnan V, Robinson JP, Ramakrishnan M. Anticancer and apoptosis-inducing effects of Moringa concanensis using hepG2 cell lines. Bangladesh J Pharmacol. 2014; 9(4):604-09.

Beltrame FL, Pessini GL, Doro DL, Filho BPD, Bazotte RB, Cortez DAG. Evaluation of the anti diabetic and antibacterial activity of Cissus sicyodes. Braz Arch Biol Technol. 2002;45(1):21-25.

Chun-Fai NG, Chun-Hay KO, Chi-Man K, Jia-Wen X, PingChung L, Kwok-Pui F, Ho YEC, Clara B-SL. The aqueous extract of rhizome of gastrodia elata protected drosophila and PC12 cells against beta-amyloid-induced neurotoxicity. EvidBased Complem Altern Med. 2013;5(1):1-12.

Erukainure OL, Oke OV, Owolabi FO, Kayode FO, Umanhonlen EE, Aliyu M. Chemical properties of Monodora myristica and its protective potential against free radicals in vitro. Oxid Antioxid Med Sci. 2012;1(2):127-132.

Hamburger M, Hostettmann K. Bioactivity in plants: the link between phytochemistry and medicine. Phytochemist ry.1991;30(12):3864-3874.

Jordan MA. Mechanism of action of antitumor drugs that interact with microtubules and tubulin. Anticancer Agents Med Chem. 2002;2(1):1-17.

Khare CP. Indian medicinal plants and illustrated dictionary. New Delhi: Springer Science Publishers; 2007. 900 p.

Marzouk M, Gamal-Eldeen A, Mohamed M, El-Sayeed M. Antiproliferative and antioxidant constituents from Tecoma stans. Z Naturforsch C. 2006;61(11-12):783-791.
Ochuko LE, Oluwatoyin VO, Folashade OO, Funmi OK, Emmanuel EU, Muhammad A. Chemical properties of Monodora myristica and its protective potentials against free radicals in vitro. Oxid Antioxid Med Sci. 2012;1(2):127-132.

Owen RW, Giacosa A, Hull WE, Haubner R, Spiegelhalder B, Bartsch $\mathrm{H}$. The antioxidant/anticancer potential of phenolic compounds isolated from olive oil. Eur J Cancer. 2000; 36(10):1235-47.

Prajapati DK, Patel NM. Pharmacognostic and phytochemical investigations of the leaves of Tecoma Stans Linn. Int J Pharm Sci Rev Res. 2010;3(1):70-72.

Pusapati MR, Nagarani T, Swathi V, Pahni KK, Chowdary YA, Siva Reddy CH, Girijasankar G. Evaluation of phytochemical content and In vitro cytotoxic activity of various ornamental plant flower extracts against MCF-7 Cell lines. Int J Curr Res Life Sci. 2015;4(3):172-176.

Suffredimi IB, Sader HS, Gonçalves AG, Reis AO, Garles AC, Varella AD, Younes RN. Screening of antibacterial extracts from plants nature to the Brazilian amazon rain forest. Braz J Med Biol Res. 2004;37(3):379-384.

Tailor CS, Goyal A. Antioxidant activity By DPPH radical scavenging method of Ageratum conyzoides Linn. Leaves. Am J Ethnomed. 2014;1(4):244-249.

Terry BJ, Liu WC, Cianci CW, Proszynski E, Fernandes P, Meyers E. Inhibition of Herpes Simplex virus type I DNA polymerase by the natural product Oosporein. J Antibiot. 1992;45(2):286-288.

Received for publication on $21^{\text {st }}$ November 2016 Accepted for publication on $10^{\text {th }}$ January 2017 